\title{
A fabricação da alteridade nos museus da América Latina: representações ameríndias e circulação dos objetos etnográficos do século XIX ao XXI
}

The fabrication of otherness in Latin American museums: Amerindian representations and circulation of ethnographic objects from the 19th to the 21 st century

\section{GLÓRIA KOK'}

Universidade de São Paulo / São Paulo, SP, Brasil

RESUMO: Este artigo lança luz sobre representações ameríndias elaboradas em museus e baseadas em objetos, que reificaram certas imagens em circulação até os dias de hoje. Se, no século XIX, os habitantes da América eram representados como extintos, em vias de extinção ou com sinais visíveis de degenerescência, no século XXI, numa reviravolta histórica, os povos ameríndios criaram suas próprias representações e objetos, apropriando-se dos museus como espaços de mobilização pelos direitos e de reconstrução de suas próprias trajetórias, lutas, memórias e identidades.

PALAVRAS-CHAVE: Ameríndios. Representações. Museus. Objetos etnográficos. Museus indígenas.

ABSTRACT: This article intends on highlighting the Amerindian representations elaborated in museums and based on the objects that reified certain images that circulate until the present day. If, in the nineteenth century, the inhabitants of America were represented as extinct, on the verge of extinction or with visible signs of degeneracy, in a historical turnaround during the twenty-first century, the Amerindian populations created their own representations and objects, appropriating museums as spaces of mobilization for rights and reconstruction of their own trajectories, struggles, memories and identities.

KEYWORDS: Amerindians. Representations. Museums. Ethnographic objects. Indigenous museums.

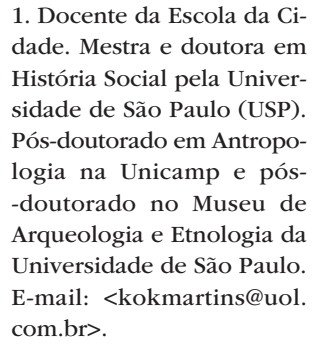

1. Docente da Escola da Cidade. Mestra e doutora em História Social pela Universidade de São Paulo (USP). Pós-doutorado em Antropologia na Unicamp e pós-doutorado no Museu de Arqueologia e Etnologia da Universidade de São Paulo. E-mail: <kokmartins@uol. com.br>. 
2. Stocking (1985, p. 11).

3. Grupioni (2008, p. 21-22).

4. Abreu (2008, p. 11).

5. Leroi-Gourhan apud POMIAN (1984, p. 70-71).

6. Cf. Mauss (2003).

7. Para uma análise mais aprofundada das inovações metodológicas da etnografia, cf. Clifford (1988).

8. Malinowski (1976, p. 79). 9. Clifford (1988, p. 196).
Certainly in Western museums there has been some rethinking of problems of representation. Not only radical critics, but establishment museologists now raise questions about the situation of non-European others along with animals and plants in the museums of natural history, or their segregation from the rest of world history in museums of ethnography.

George W. Stocking Jr.2

\section{A PRÁTICA DO COLECIONAMENTO NO OCIDENTE MODERNO}

A prática de formar coleções, ou melhor, a prática de colecionamento de objetos e espécies é inerente a qualquer sociedade humana, uma atividade que, por meio de evidências materiais, visa a compreensão e/ou o domínio do mundo. ${ }^{3}$ O conceito de colecionamento, desenvolvido pelo antropólogo James Clifford, se refere a uma operação mental que compreende uma prática universal, presente em todas as sociedades, relacionada ao impulso de hierarquizar, ordenar e classificar, associado à dinâmica da lembrança e do esquecimento e ao esforço de conhecer o mundo. ${ }^{4}$

Os primeiros colecionadores de que se tem notícia são os habitantes da gruta de Hyène, em Arcy-sur-Cure, que guardavam uma coleção de curiosidades naturais, como uma concha em espiral de um molusco da era secundária, um polipeiro de forma esférica, blocos de pirite de ferro etc. ${ }^{5} \mathrm{Em}$ várias sociedades, a acumulação de bens é um atributo do chefe, que os redistribui entre os membros da aldeia, geralmente em festas rituais, como no caso da Melanésia ou do potlatch dos índios do noroeste norte-americano. ${ }^{6}$

O etnógrafo Bronislaw Malinowski (1884-1942), responsável pela atribuição de importância ao trabalho de campo e ao papel do "observadorparticipante" na etnografia, observa a relevância da circulação de colares e braceletes no sistema kula dos grupos que habitavam as ilhas Trobriand, cujo significado simbólico é semelhante ao das joias da Coroa exibidas em vitrines para o mundo ocidental. ${ }^{8}$

Nos séculos XVI e XVII, com a expansão ultramarina dos europeus, renovouse o interesse pelos objetos coletados na Ásia, na África, na América e na Oceania, que no Ocidente moderno tornaram-se símbolos da acumulação de posses e de poder. ${ }^{9}$ Nesse sentido, as viagens ultramarinas cumpriam um papel fundamental na prática do colecionamento, viabilizando não apenas a coleta de objetos desconhecidos, mas também o fluxo de produtos e de saberes para a Europa. 
O critério de seleção, na maioria das vezes, era o exotismo: um acervo de objetos estranhos que representasse os três reinos, animal, vegetal e mineral. No que diz respeito à classificação dos objetos, era frequente dividi-los em duas categorias: naturalia, objetos feitos pela natureza, e artificialia, objetos feitos pelo homem. Por meio de um objeto (ou parte dele), os europeus pensavam conhecer uma população distante. ${ }^{10}$

Assim, espécies e artefatos das coleções de arte, de maravilhas, de raridades e de curiosidades trazidos das viagens transoceânicas amontoavam-se nos gabinetes de curiosidade dos nobres e naturalistas europeus, tornando-se signos de prestígio para os colecionadores da época. Nesse sentido, a coleção de João Maurício de Nassau (1604-1679), exibida tanto no Brasil quanto na Holanda, é reveladora, pois ilumina o capital político mobilizado por seu dono. Nassau fazia alianças políticas com representantes dos governos europeus distribuindo peças de sua coleção. ${ }^{11}$

Uma série de artefatos de origem americana estava presente em coleções europeias dos séculos XVI e XVII: artefatos feitos de penas, mosaicos mexicanos, esculturas em pedra, objetos em cerâmica, cintos e colares, propulsores de flechas, bacias de madeira, bordunas, lanças, machados, instrumentos musicais, pentes, redes, cachimbos e bastões cerimoniais. ${ }^{12}$

Entre o final do século XIX e o início do XX, artefatos coletados por viajantes, missionários e etnólogos, foram denominados "objetos etnográficos" e passaram a ocupar os espaços institucionais dos museus da Europa e dos Estados Unidos. "Aos poucos, os museus etnológicos transformam-se em depósitos ordenados de uma cultura material fetichizada e submetida à lógica evolutiva". ${ }^{13}$

Alvos de colecionamento, classificação e exibição nos museus, tais objetos foram valorizados pelo exotismo e pela raridade, sendo vistos como "traços culturais" fossilizados por meio dos quais se entendia o passado das sociedades ditas "primitivas", que tenderiam fatalmente ao desaparecimento. Daí o esforço de conservá-los (Figura 1).

No entanto, é preciso frisar que um objeto etnográfico carrega um feixe de significados para a sociedade que o produziu diverso daquele engendrado pelos colecionadores e coletores. ${ }^{14}$

Objetos que mudam de contexto e de função se tornam descontextualizados e desfuncionalizados, e são considerados rotineiramente "desfigurados", o que coloca em pauta a complexa questão da reintrodução desses objetos em diferentes âmbitos da pesquisa e do trabalho museológico, da catalogação à exposição. ${ }^{15}$
10. Clifford (1988, p. 227).

11. Françoso (2014, p. 232). Uma coleção confere prestígio e poder aos colecionadores (Pearce, 2002, p. 158; Miller, 2013, p. 14).

12. Françoso (2014, p. 55).

13. Schwarcz (2007, p. 69).

14. Pearce (2002, p. 130).

15. Van Velthem (2012, p. 57). 
16. Grupioni (2008, p. 22-23).

17. Ribeiro; Van Velthem (1998, p. 105).

18. Van Velthem (2012, p. 52).

19. Berger (1972, p. 8).

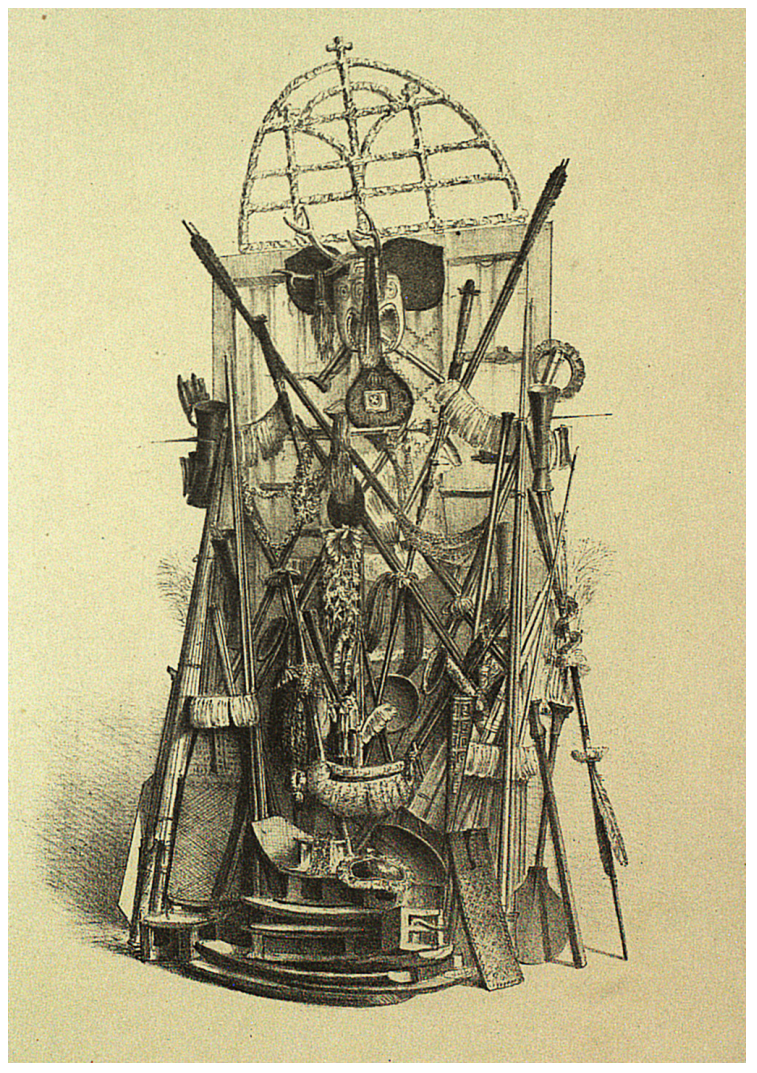

Figura 1 - Peças da Amazônia reunidas por Gonçalves Dias para a Exposição Nacional de 1861. Litografia do Instituto Artístico. Acervo da Fundação Biblioteca Nacional.

"Documentos materiais das mais diversas formas de atividade humana", as coleções etnográficas "se constituíam no registro palpável da diferença e, antes que essa desaparecesse, era fundamental aprisioná-la para que ela fosse preservada, estudada e exibida". ${ }^{16}$

O colecionamento do final do século XIX, portanto, tinha basicamente dois objetivos: evitar a perda total das culturas dos povos indígenas, consideradas em vias de extinção, e ampliar a compreensão da origem e da evolução humana. ${ }^{17}$ Atualmente, os museus etnográficos ou de história natural são considerados importantes "arquivos da cultura material" dos povos nativos. ${ }^{18}$

\section{OS MUSEUS NA LÓGICA DO COLONIALISMO}

A visão, segundo o crítico de arte John Berger (1926-2017), é influenciada pelo que conhecemos ou acreditamos, modelada pela grade cultural na qual o sujeito está inserido: "Só vemos aquilo que olhamos. Ver é um ato de escolha". ${ }^{19}$ 
Desde a Revolução Francesa, quando as coleções privadas passaram a ser abertas ao público e os palácios da aristocracia se transformaram em museus, legitima-se o modelo de "museu da nação", 20 etnológico ou histórico, que elege o patrimônio como "um lugar central na representação da nação". ○ museu se transforma em monumento, lugar da memória da nação, onde é possível identificar elementos comemorativos da história nacional.

Desde a segunda metade do século XIX, este modelo propaga-se nos Estados-nação da Europa e nos Estados Unidos, por um lado fabricando uma nacionalidade (branca e "civilizada"), por outro, promovendo a exclusão daqueles que não eram europeus, considerados "inferiores", "exóticos", "primitivos", "bárbaros" e "selvagens", difundindo narrativas textuais e imagéticas classificatórias, hierarquizantes, hegemônicas e totalizantes. Na lógica do colonialismo, ${ }^{21}$ os povos que não viviam na Europa eram vistos como criaturas que se encontravam nos limiares da humanidade, em uma perspectiva que servia à legitimação tanto da escravidão como da organização do império colonial.

Os antropólogos dessa época, impregnados pelas ideias de progresso e superioridade do homem branco, europeu e "civilizado", debatiam sobre a evolução das espécies das formas simples às complexas por meio de um progresso contínuo, e procuravam explicar tanto a origem da humanidade como as diferenças entre os grupos étnicos influenciados pelo determinismo biológico, pelo paradigma evolucionista e pela antropologia física, com seus métodos antropométricos. "Esta argumentação se torna, então, útil para uma Europa que procura ampliar o seu espaço de dominação mediante a política colonialista que caracterizou a história do século XIX" ${ }^{22}$

Nessa perspectiva, enquadram-se as exposições organizadas de 1877 a 1931, com a presença de grupos étnicos da África, da América e da Ásia, nas quais os denominados "selvagens" foram exibidos em cenários exóticos para milhões de visitantes na Europa e nos Estados Unidos. Tais eventos de massa influenciaram e moldaram a mentalidade europeia e norte-americana quanto à construção da alteridade, do outro e de sua exterioridade selvagem.

A celebração dos cem anos da Revolução Francesa e de seus ideais de "liberdade, igualdade e fraternidade", em Paris, no ano de 1889, se deu com a inauguração da Tour Eiffel e a Exposition Universelle, ${ }^{23}$ símbolos da modernidade. Realizada na Esplanade des Invalides, a exposição, que representava uma "vila de negros" e seus quatrocentos africanos (Figura 2) atraiu 28 milhões de pessoas - um verdadeiro espetáculo de massa, no qual a identidade francesa se articulou ao Império colonial, composto por diversidades. Tratava-se da integração do imaginário coletivo no universo imperial e heterogêneo, e da edificação de um
20. Iniesta (2001, p. 25, tradução minha). 21. "Colonialism is a prac-
tice of domination, which
involves the subjugation of
one people to another. [...]
Colonialism, then, is not
restricted to a specific time
or place. Nevertheless, in
the sixteenth century, colo-
nialism changed decisively
because of technological
developments in naviga-
tion that began to connect
more remote parts of the
world. Fast sailing ships
made it possible to reach
distant ports and to sus-
tain close ties between the
center and colonies. Thus,
the modern European co-
lonial project emerged
when it became possible
to move large numbers of
people across the ocean
and to maintain politi-
cal sovereignty in spite of
geographical dispersion.
This entry uses the term
colonialism to describe the
process of European settle-
ment and political control
over the rest of the world,
including the Americas,
Australia, and parts of Af-
rica and Asia" (Colonialism,
2018).

22. Laraia (2005, p. 322).

23. As exposições universais de Paris ocorreram em $1855,1867,1878,1889$ e 1900. Segundo Camille Mazé, foi a partir da Exposição Universal de 1878, em Paris, que os museus de etnologia nacional floresceram em toda a Europa (Mazé, 2008, p. 130). 
24. Bancel; Blanchard; Lemaire (2000, p. 17).

25. Iniesta (2001, p. 26, tradução minha).

26. Para o filósofo Paul Ricoeur (1913-2005), o campo da história das representações seria o mais adequado para a museologia histórica, na medida em que a palavra "representação" pressupõe a memória (presença na mente) de uma coisa ausente (Moreno, 2015, p. 201). império colonial que fabricava a alteridade a partir da hierarquização das "raças" e da construção de um imaginário social sobre o outro. ${ }^{24}$

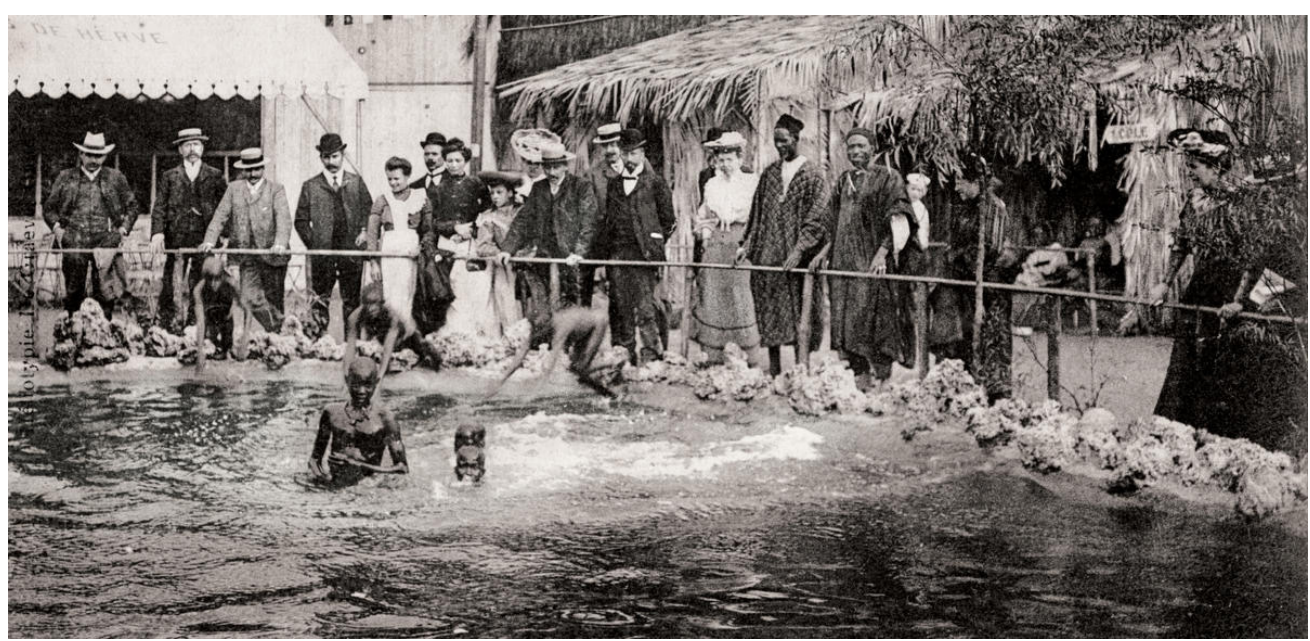

Figura 2 - Vila senegalesa. Exposição Universal de Liège. Cartão Postal, heliotipia, 1905. Fonte: Zeitoun (2015).

A exposição colonial realizada no palácio Porte Dorée, em Paris, em 1931 , serviu de modelo para as exposições dos museus latino-americanos, logo depois da independência dos países, na esteira dos ideais de construção de uma nação moderna.

Em um processo aparentemente paradoxal, as novas nações adotam, para reivindicar seu direito à autonomia e à existência, as mesmas linguagens e sistemas de representação das nações das quais se libertaram. Embora não se diga de forma explicita, o museu nacional de cada nova nação pode ser integrado em um programa político do espaço público que supere o estrito âmbito museológico. ${ }^{25}$

Os museus da América Latina assumiram, então, o papel de fabricação e legitimação de narrativas visuais e estratégias de representação ${ }^{26}$ das populações autóctones, conferindo-thes a condição de selvagens, presos ao passado de origem da nação. Os objetos etnográficos, por sua vez, foram inscritos fora da temporalidade moderna, passando a ser exibidos como relíquias.

Deste modo, por meio de objetos, imagens, símbolos e memórias, os museus investiram em uma produção simbólica articulada à narrativa para forjar as identidades nacionais sul-americanas, calcadas em fatos históricos e nas figuras dos heróis, que se inscrevem no presente hegemônico e na história dos países. As independências como atos heroicos foram os eixos articuladores do passado que 
serviu de base para a construção da nação definida como "uma comunidade política imaginada" ${ }^{27}$

No entanto, o processo de construção das nações americanas foi permeado pela violência, marco cultural do colonialismo. ${ }^{28}$ Isto significa que os museus latino-americanos, enquanto "terreno fértil para a manipulação das identidades", ${ }^{29}$ municiam a construção da memória de uma nova elite mestiça que assume o poder político e a preservação do patrimônio nacional, com seus heróis, elementos simbólicos, feitos, fatos e monumentos, em detrimento dos povos autóctones. É bom lembrar que o índio que constrói a identidade ${ }^{30}$ americana diante do mundo europeu é um índio imaginado, inventado, e não um sujeito histórico. ${ }^{31}$

No caso do Museu Nacional do México, o discurso da identidade nacional atrelava-se às 75 espécies monstruosas que enchiam a seção de teratologia, como um gigante, siameses, hermafroditas, seres de duas cabeças conservados em álcool e outras criaturas dissecadas ou representadas por fotografias. ${ }^{32}$

O tema polêmico da origem do povo mexicano era central na organização dos conteúdos do Museu Nacional. Tratava-se de saber se a raça mexicana pode ser considerada "normal", segundo os padrões europeus, "ou se constitui uma variação patológica dessa espécie". As singularidades das raças americanas eram ressaltadas e necessitavam explicações científicas. Uma delas, em voga nas discussões dos meios intelectuais, referia-se às medidas dos crânios mexicanos, que seriam inferiores às medidas totais obtidas na Europa". ${ }^{33} \bigcirc$ evolucionismo em curso elaborava, por vários artifícios, diferentes hipóteses que comprovassem a inferioridade das populações nativas e sua posição na contramão da modernidade.

Os indígenas reais da árida paisagem do norte, como os yaquis ou os maias do sudeste, foram transformados em anti-modernos ou, melhor dizendo, a modernização tecnológica e econômica os colocou em uma posição conservadora ou abertamente reacionária. Sua exterioridade ao mundo do progresso e da integração mestiça os fez parecer como exóticos, como simples restos de antiguidade e, às vezes, como divisão da nação mexicana. ${ }^{34}$

Com relação à "monstruosidade" atribuída pelos europeus à população nativa do Novo Mundo, destaca-se o caso de Julia Pastrana (1834-1860) (Figura 3), uma mulher de origem indígena, nascida no estado de Sinaloa, no México, que sofria de hipertricose, exposta publicamente como "a mulher mais horrível de todos os tempos" "a mulher-macaco", "a mulher-urso", "a completa selvagem". O empresário Theodore Lent, que se tornou seu marido, acumulou uma notável fortuna organizando exibições públicas de Julia Pestrana pelos Estados Unidos e pela Europa. Ela faleceu durante o trabalho de parto em Moscou, sob os olhos curiosos do público, sendo depois embalsamada e levada para turnês em vários países.
27. Anderson (2008, p. 32). $\mathrm{O}$ autor ainda explica que qualquer comunidade é imaginada. O que difere é o estilo em que é imaginada. O nacionalismo inventa nações onde elas não existem limitadas, porque possuem fronteiras e soberania para zelar pela liberdade (Anderson, 2008, p. 34).

28. Londoño (2012, p. 737).

29. Meneses (1993, p. 211).

30. Na análise do historiador Ulpiano Bezerra de Meneses, a raiz da palavra identidade, do grego idios, se refere a "mesmo", "si próprio", "privado", o que significa que pressupõe "semelhanças consigo mesmo, como condição de vida biológica, psíquica e social”, estando associada mais aos "processos de reconhecimento do que de conhecimento" (Meneses, 1993, p. 208).

31. Muratorio (1994, p. 364 e 368).

32. Gorbach (2001, p. 58).

33. Gorbach (2001, p. 61 e 63).

34. Moreno (2015, p. 196). 
36. De início, o Museu Nacional contava com uma pequena "coleção de arte, gravuras, objetos de mineralogia, artefatos indígenas, animais empalhados e produtos naturais", instalada na sede do Arquivo Nacional (Schwarcz, 1993, p. 70). Depois de décadas de ostracismo, o Museu Nacional do Rio de Janeiro ganhou um novo impulso, sob as administrações de Ladislau Netto (1874-93) e de Batista Lacerda (1895-1915), responsáveis pelo aumento das coleções de zoologia, botânica e geologia, pela formação de uma pequena seção de antropologia e pela criação de uma revista trimestral, os Archivos do Museu Nacional. Já no primeiro número, o próprio J. B. Lacerda escreve um ensaio sobre a "anthropologia das raças indígenas no Brasil" (Schwarcz, 1993, p. 74), indicativo da relevância do tema naquele momento.

37. Quijano (2005, p. 227).

38. As populações nativas foram classificadas, desde o período colonial, a partir do binômio Tupi/Tapuia. O processo de dominação e conquista dos povos indígenas, entretanto, redefiniu as fronteiras do continente americano de modo a significar não apenas o limite de um domínio territorial e geográfico, mas, sobretudo, um divisor de águas entre etnias distintas, classificadas e construídas conforme as políticas de alianças e inimizades vigentes entre os grupos indígenas, mas que, durante as guerras de conquista, foram isolados e cristalizados como mônadas, por exemplo, Tupinambá e Tupiniquim, Tupi e Tapuia (Monteiro, 2001, p. 13).
Os objetos arqueológicos do Museu Nacional do México foram exibidos como petrificações do passado, sem qualquer ligação com os povos indígenas contemporâneos. A cisão profunda entre a arqueologia e a etnografia justificava a impossibilidade do retorno ao passado. O museu, através de uma "hábil alquimia ideológica, fornece o passado petrificado dos índios como o verdadeiro de todos os mexicanos". ${ }^{35}$
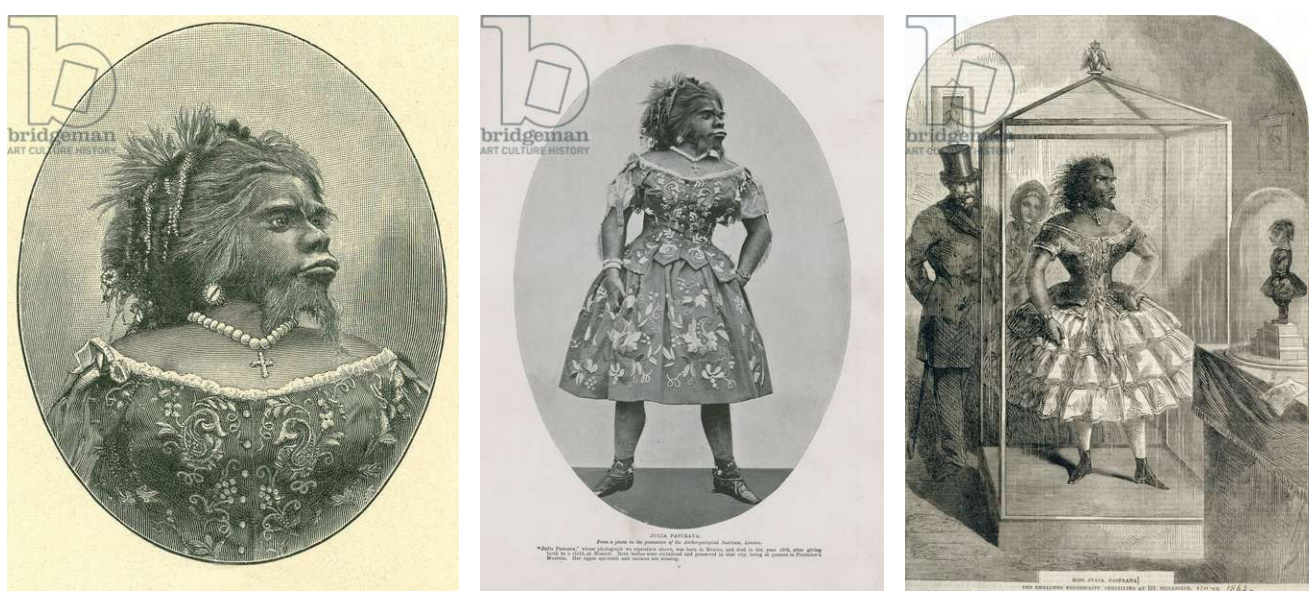

Figura 3 - Gravuras que representam Julia Pastrana, "la mujer más horrible de todos los tiempos". Fonte: Bridgeman Images e Wellcome Library.

\section{A FABRICAÇÃO DO OUTRO NO BRASIL}

No Brasil, as ideias evolucionistas de progresso e de superioridade do branco na cadeia evolutiva eram predominantes nos meios científicos e intelectuais do Império. O Museu Nacional, ou Museu Real do Rio de Janeiro, 36 fundado por decreto de d. João VI (1767-1826) em 1818, refletiu a política indigenista do recém-criado Estado-nação, cujo objetivo era invisibilizar as populações indígenas, seja pelo extermínio ou por sua assimilação à "civilização" e ao "branqueamento" das raças, de modo a eliminar as diferenças sob o manto de uma só nacionalidade. A ideia de raça, em seu sentido moderno, não tem história conhecida antes da América. Ela produziu identidades sociais historicamente novas - índios, negros e mestiços - e redefiniu outras. ${ }^{37}$

Ao longo do Império, entre 1822 e 1889, a dualidade Tupi/Tapuia ${ }^{38}$ se radicalizou com a ideia de raça como elemento classificatório que estabelecia e justificava as relações coloniais de dominação entre europeus e não europeus. Nessa lógica classificatória, as populações indígenas foram consideradas 
naturalmente inferiores pelos conquistadores europeus, devido aos traços fenotípicos, mentais e culturais, perceptíveis durante o Império em duas imagens antagônicas e complementares sobre os índios genéricos. Os Tupi, ou "índios mansos", falantes da língua do tronco Tupi, foram valorizados enquanto índios mortos, enraizados no passado pré-colonial, legitimando a construção do Império. Já os Tapuia, os "índios bravos dos sertões", que os jesuítas diziam ter "língua travada", tornaram-se objetos privilegiados de investigações científicas. Tais imagens antagônicas provocaram acalorados debates entre intelectuais - escritores, juristas, médicos - a respeito do futuro da nação.

Se os Tupi, na condição de mortos e extintos, foram idealizados como símbolo do Estado "civilizador" brasileiro, os índios Tapuia, que viviam nos "sertões incultos", como os famosos "Botocudos", além de terem sido alvo da violência das guerras de conquista para a expropriação de suas terras, foram "selecionados" como objeto de estudo da ciência brasileira.

Nesse contexto, o que estava em pauta nos debates intelectuais da elite do Brasil era, em última instância, o consenso quanto à impossibilidade de "ser índio" no Império e a discordância quanto ao modo de seu desaparecimento do cenário nacional. José Bonifácio de Andrada (1763-1838) acreditava que os índios tinham capacidade de se civilizar por meio da assimilação branda, ${ }^{39}$ enquanto o historiador Francisco Adolfo de Varnhagen (1 81 6-1 878) era favorável à violência, à guerra e ao extermínio. ${ }^{40}$ Tais posições em relação aos grupos indígenas persistem até os dias de hoje, contando com muitos adeptos entre a população brasileira.

\section{O "BOM MORTO"}

A obra de José de Alencar (1829-1877), Iracema: lenda do Ceará, publicada em 1865, representa a impossibilidade de "ser índio" no Império. A personagem principal, Iracema, é uma índia Tabajara, filha do cacique e guardiã da bebida jurema. $\bigcirc$ romance nativista narra 0 encontro impossível entre 0 português Martim e Iracema, que deixa a sua aldeia originária para seguir o conquistador e ir viver no litoral, entre os Potiguara, inimigos históricos dos Tabajara.

Da união, nasce o mameluco Moacir, representante de um país de mestiços, ao qual se confere o "álibi duma raça heroica, e a uma nação de história curta, a profundidade do tempo lendário". ${ }^{41}$ Anos depois, Iracema é abandonada por Martim, que não resiste aos apelos da civilização, regressando definitivamente a Portugal. Desterrada em sua própria terra, a índia falece de inanição e tristeza. 
Outro escritor romântico, o maranhense Antônio Gonçalves Dias (18231864), canta na introdução de seu poema, Os Timbiras, publicado em 1857 :

$[\ldots]$

As festas, e batalhas mal sangradas

Do povo Americano, agora extinto,

Hei de cantar na lira. - Evoco a sombra

Do selvagem guerreiro!

$[\ldots]$

Além de poeta indianista, o maranhense Gonçalves Dias atuou como chefe da seção etnográfica e narrativa de viagem da Comissão Científica de Exploração do Império, apoiada pelo Imperador Pedro II e pelo Instituto Histórico e Geográfico Brasileiro, entre 1859 e 1861.

A primeira expedição científica nacional percorreu as províncias do Ceará, incursionou pelos rios da Amazônia, produziu numerosos diários e coletou objetos indígenas, muitos dos quais foram posteriormente incorporados à coleção do Museu Nacional (Figura 4).

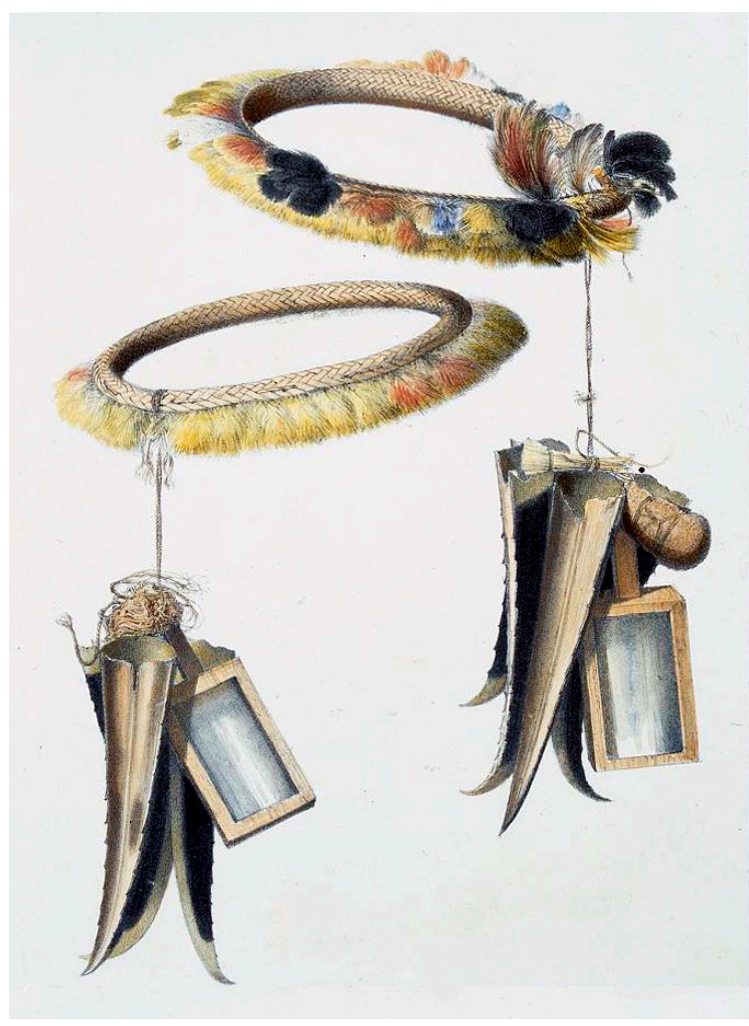

Figura 4 - Gravura colorida da empresa tipográfica Fleiuss, Irmãos e Linde representando anel próprio para a cabeça da região do rio Uaupés, usado em cerimônias rituais. Possui pingentes com bicos de tucanos e objetos industrializados, provavelmente espelhos. Acervo da Fundação Biblioteca Nacional. 
Para Gonçalves Dias, os índios "caminhavam precípites para a sua completa decadência". ${ }^{42} \bigcirc$ interesse do poeta pelas populações indígenas coadunava-se perfeitamente com o pensamento sobre a formação do povo brasileiro, baseado na hierarquia das raças e na ideia da decadência dos índios.

No campo pictórico, Moema (Figura 5), de Victor Meirelles de Lima (18321903), retrata uma jovem índia morta à beira do mar, provavelmente afogada, com os cabelos soltos e o corpo nu sobre as areias. Ao fundo, a mata exuberante compõe a paisagem. Mais uma vez, o olhar romântico revela que a mulher indígena, que concedeu o ventre para gerar os mamelucos, era apenas um símbolo ou uma lenda do passado, sem futuro:

[...] a tela conjuga a grande obsessão sensual do tempo, que se repete incansavelmente nas artes internacionais, com o romantismo indianista que se carrega aqui de maresias longínquas. Porque Meireles opera a transfiguração estilística capaz de conduzir a imagem para a fronteira tênue entre a sedução sensível e a beleza da forma. ${ }^{43}$

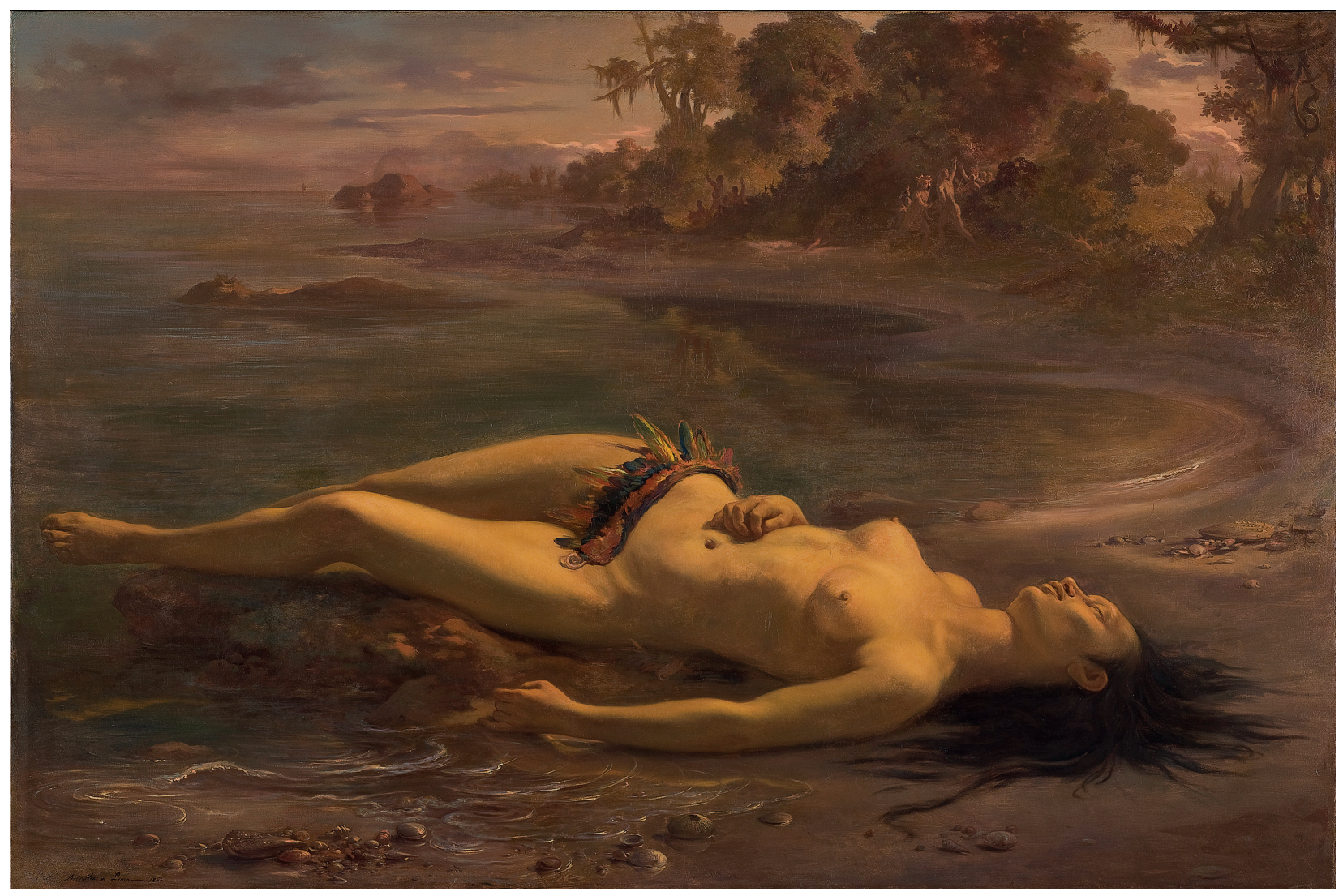

Figura 5 - Victor Meirelles, Moema, 1866, óleo sobre tela, 130 × 196,5cm. Doação Indústrias Químicas e Farmacêuticas Schering S.A. (1949). Inv. MASP.00267 Coleção Museu de Arte de São Paulo Assis Chateaubriand, São Paulo. Foto Alexandre Cruz Leão. 
44. Scrich (2009, p. 391).

45. Scrich (2009, p. 391).

46. Carneiro da Cunha (1992, p. 20).

47. Cf. Monteiro (2001).

48. Carneiro da Cunha (1992, p. 22).
O artista Rodolfo Amoedo (1857-1941), em O último Tamoio (Figura 6), representa o cadáver de Aimberê, o chefe dos Tamoios, encontrado na praia pelo padre jesuíta Anchieta. Ambos são personagens do livro A Confederação dos Tamoios (1857), de Gonçalves de Magalhães (1 81 1-1882), que toma "o sacrifício indígena como marco fundador da nação brasileira". ${ }^{44}$ No caso, "há, sim, a eliminação da diferença, a incompreensão do outro, uma crucificação arquitetada por quem se julgava amigo do indígena. Não crer no Deus do branco civilizado custou a eliminação da alteridade". ${ }^{45}$ Os índios mortos, "pacificados" e idealizados de Alencar, Gonçalves Dias, Meirelles e Amoedo representavam "o bom índio TupiGuarani (convenientemente, um índio morto), que é símbolo da nacionalidade". ${ }^{46}$

O projeto civilizatório da sociedade brasileira, na segunda metade do século XIX, almejava um país mestiço, com "um só povo", o que implicava, necessariamente, o fim das culturas indígenas. A perspectiva de aculturação previa os índios assimilados ou integrados à sociedade e, portanto, "menos" índios. ${ }^{47}$ "Durante quase cinco séculos, os indígenas foram pensados como seres efêmeros, em transição: transição para a cristandade, a civilização, a assimilação o desaparecimento". ${ }^{48}$

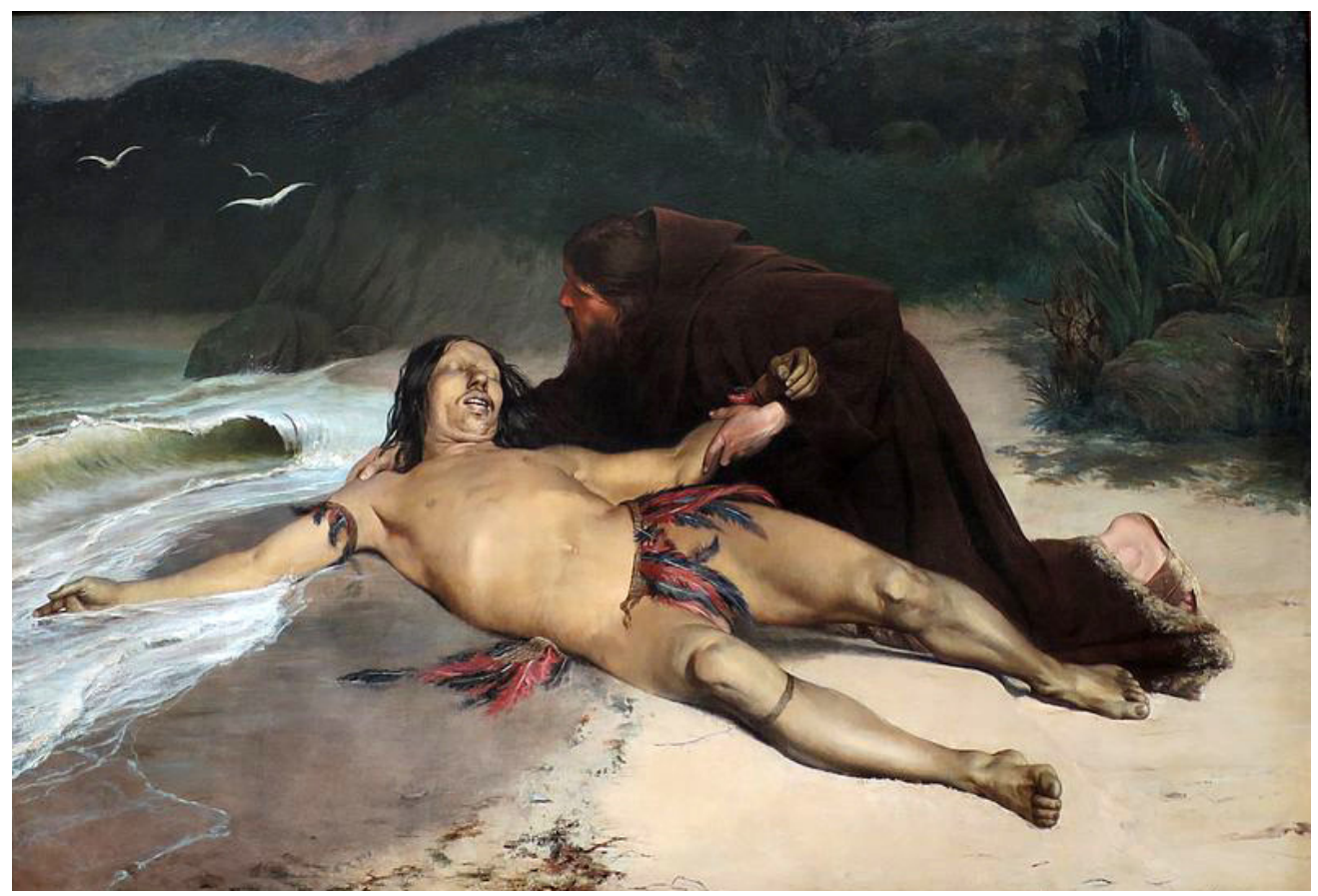

Figura 6 - Rodolfo Amoedo, O último Tamoio, 1883, óleo sobre tela, 180,3 × 261,3 cm, Museu Nacional de Belas Artes, Rio de Janeiro. In: ENCICLOPÉDIA Itaú Cultural de Arte e Cultura Brasileiras. São Paulo: Itaú Cultural, 2018. Disponível em: <https://bit.ly/2GPdGYe>. Acesso em: 25 de Maio 2018. Verbete da Enciclopédia. ISBN: 978-85-7979-060-7 
Os cadáveres dos Tupi-Guarani, portanto, estão na base da fundação da nação brasileira, enquanto os índios bravos dos sertões incultos eram "domesticados" de várias maneiras: mortes, guerras, escravidão, expropriação de terras, investigações ditas científicas, fotografias e exposições nacionais e internacionais.

\section{OS "SELVAGENS" DOMESTICADOS}

Em seu célebre texto, "Como se deve escrever a História do Brasil", de 1845, Carl Friedrich Philipp von Martius (1794-1868) aponta que "o triste e penível quadro, que nos oferece o atual indígena brasileiro, não é senão o residuum de uma muito antiga, posto que perdida história". ${ }^{49}$ Para ele, os índios da América deveriam ser assimilados pelo "grande 'rio' da raça branca, que deveria ser hegemônica na formação do novo povo brasileiro". ${ }^{50}$

No início do século XIX, os índios, considerados pelos naturalistas como "resíduos" em vias de extinção, chamaram atenção dos viajantes por sua radical relação de alteridade. Entre estes índios, destaca-se o grupo dos "Botocudos", assim denominados devido ao uso de botoques labiais e auriculares. Falantes do tronco linguístico Macro-Jê, os Botocudos viviam nessa época nas regiões do Mucuri e Doce, no Espírito Santo, na Bahia e em Minas Gerais.

A atribuição infundada de costumes "antropófagos" a esses índios justificou a declaração das guerras justas, em carta régia de 13 de maio de 1808. Os índios que fossem aprisionados estavam obrigados a um cativeiro de até quinze anos, e os colonos que se estabelecessem em territórios indígenas receberiam favores no sentido de promover a agricultura, o comércio e a navegação na região. Outra carta régia, de 2 de dezembro de 1808, declarava devolutas as terras que fossem "conquistadas", as quais poderiam ser concedidas aos colonos pela Coroa Portuguesa. Assim, numa guerra ofensiva em nome do "progresso", promoveu-se uma política de extermínio dos índios Botocudos. Tratava-se de "desinfestar" o caminho de índios para as frentes colonizadoras. Além da expropriação de terras pelos colonizadores, os Botocudos tornaram-se objetos cobiçados pelos estudos científicos e pela antropologia física (Figura 7).

Dois Botocudos foram expostos, pela primeira vez, na Academia de Ciências de Paris, em 1844, como espécimes vivos que exemplificavam a degeneração da humanidade. Nessa ocasião, foram realizadas as primeiras fotografias por E. Thiesson (Figura 8), que serviram de fonte para estudos comparativos no campo da antropologia física. ${ }^{51}$ 


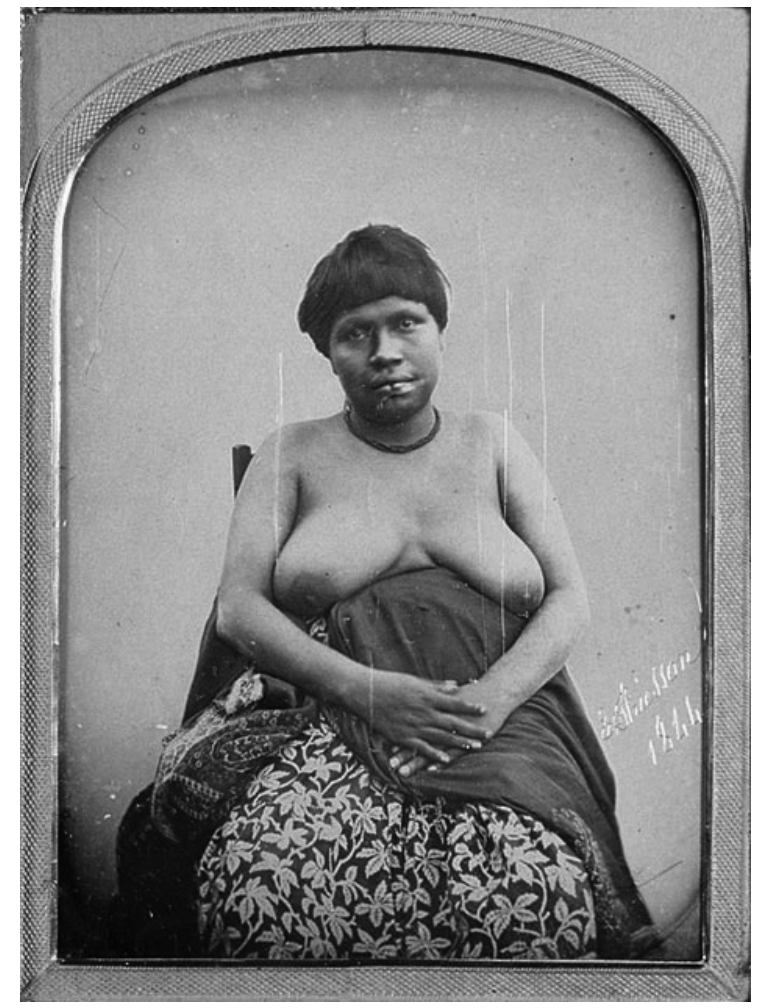

Figura 7 - E. Thiesson. Sem título, 1844. Daguerreótipo. Musée de I'Homme, Musée du quai Branly, Paris.

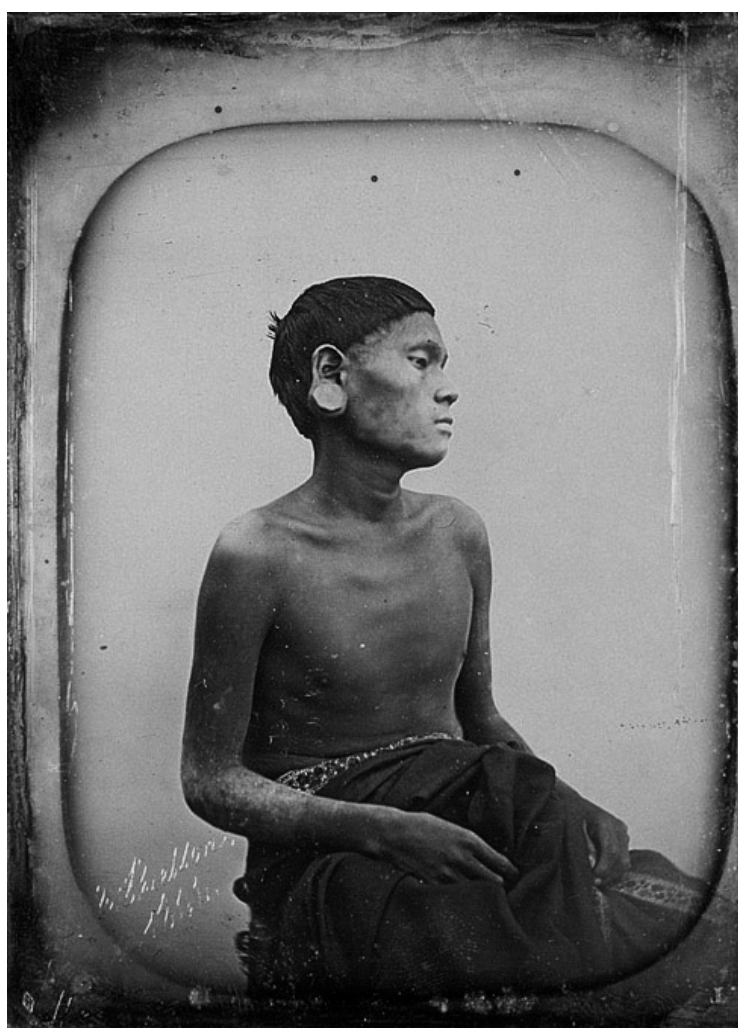

Figura 8 - E. Thiesson. Sem título, 1844. Daguerreótipo. Musée de I'Homme, Musée du quai Branly, Paris. 
As fotografias, descontextualizadas, tinham a preocupação de "domesticar" os Botocudos, comprovando as teorias científicas de degenerescência e decadência dos "selvagens".

A presença desses "selvagens" causou ebulição no meio intelectual parisiense. Foram tema de relatórios e acalorados debates na sessão de verão da Academia de Paris em 1843. Depois da discussão acadêmica, a decodificação: apalpados, medidos e enquadrados nos cânones do discurso institucional da Antropologia Física, além de registrados pela Sociedade de Geografia. ${ }^{52}$

Conforme a concepção de monogenismo, representada no Brasil pelo pesquisador francês Emmanuel Liais (1826-1900), os Botocudos encontram-se "no mais baixo grau da escala dos povos existentes", 53 e o fato de não produzirem cerâmica corroboraria essa classificação.

fotógrafo Marc Ferrez (1 843-1923), que integrou a Comissão Geológica do Império, fotografou os Botocudos na Bahia. Essas fotografias, geralmente tiradas de frente e de perfil, com as réguas de medição, retratam os índios dos sertões como um objeto a ser mensurado e dominado (um grupo de Bororos em um estúdio) na expansão do Império para os sertões.

Todas as imagens fotográficas reforçavam o pensamento de que os exóticos índios Botocudos das matas do sertão do leste estavam no grau mais baixo de civilização. Charles Hartt (1 840-1878), geólogo e diretor da seção de mineralogia do Museu Nacional, advertia: "Em alguns casos, como entre os Botocudos, podese explicar essa ignorância pelo grau extremamente baixo de cultura intelectual da tribo". 54

Como o Brasil não podia ficar para trás em relação aos eventos internacionais, os Botocudos também foram exibidos na Exposição Antropológica de 1882, no Museu Nacional, na então capital Rio de Janeiro (Figura 9). Nessa exposição, devia-se apresentar um "país 'novo': uma imagem moderna, industriosa, civilizada e científica". 55

Os índios Botocudos, outrora selvagens habitantes da floresta, foram gradativamente "domesticados" a serviço da construção do Império brasileiro, enquanto símbolo da degenerescência e do exotismo, mas à luz e sob o controle da ciência brasileira.

A modernidade do país trazia em seu bojo a eliminação das diferenças culturais e sociais em nome do progresso. Como disse o botânico e diretor do Museu Nacional do Rio de Janeiro, Ladislau Netto (1 838-1894), "o Brasil se havia tornado moderno na medida em que poderia sonhar com a sua própria antiguidade". 56
52. Morel apud Tacca (2011, p. 192)

53. Mattos (2003, p. 77)

54. Nascimento (2009, p 138).

55. Schwarcz (2007, p. 32).

56. Andermann (2004, p. 150). 
57. Schwarcz (2007, p. 69).

58. Schwarcz $(2007$, p. 91 e 93).
Além do Museu Nacional, outros museus brasileiros - como o Museu Paraense (1876), o Museu Paraense Emílio Goeldi (1866) e o Museu Paulista (1895) - foram criados no século XIX, e embora estes seguissem os padrões classificatórios dos museus europeus, cumpriram um importante papel no desenvolvimento da pesquisa etnográfica, da antropologia física e das ciências naturais no país. ${ }^{57}$ Todos eles se debruçaram sobre o "homem brasileiro" imerso, como se acreditava, em "um grande laboratório racial". ${ }^{58}$

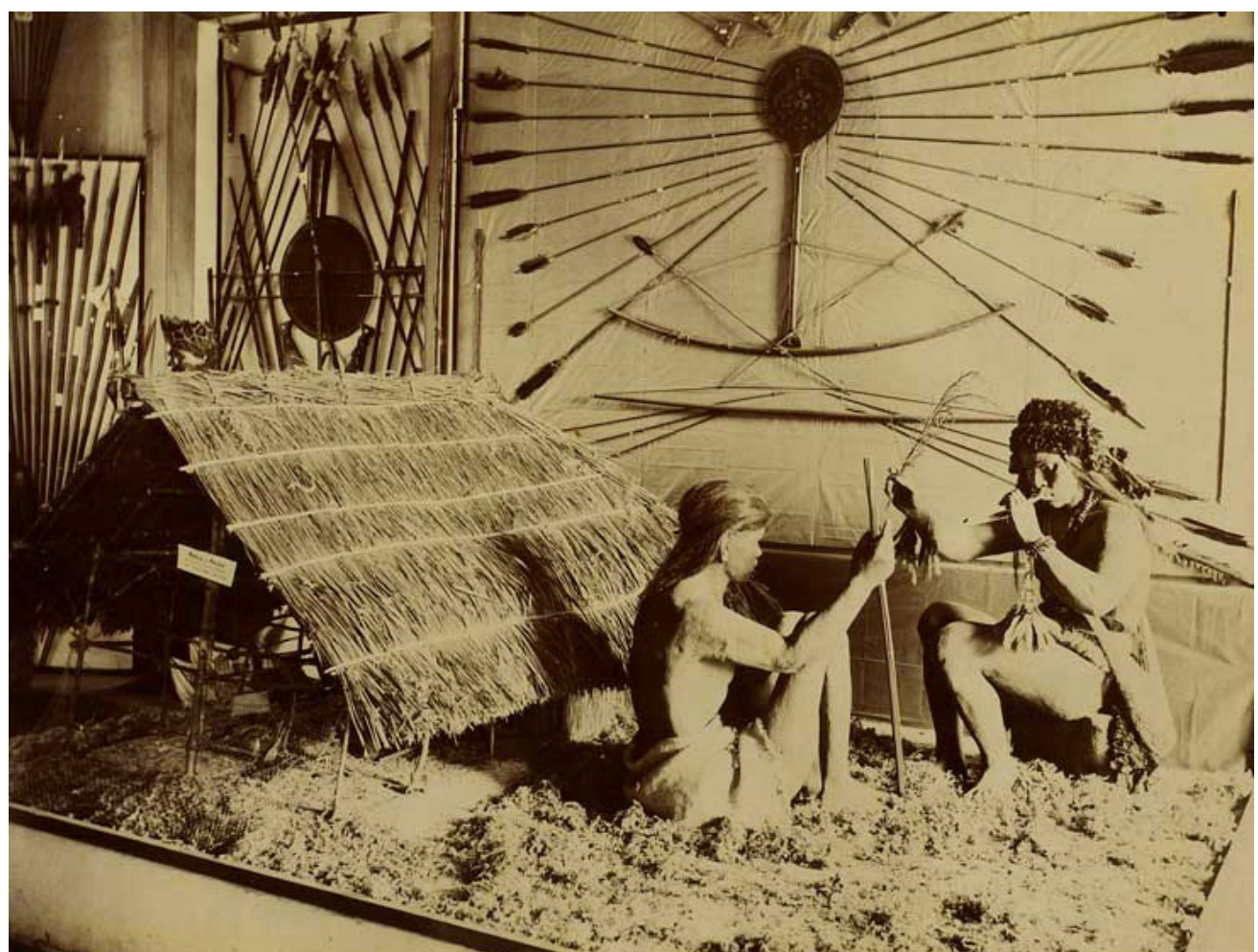

Figura 9 - Exposição Antropológica Brasileira, figuras indígenas da tribo Cherente do rio Tocantins, provavelmente em gesso, do escultor Leon Deprès, no Museu Nacional do Rio de Janeiro, 1882. Foto de Marc Ferrez. Acervo Fundação Biblioteca Nacional.

\section{OS MUSEUS INDÍGENAS}

Sob a influência da antropologia, da nova museologia e dos povos indígenas, desde a década de 1990 os museus vêm transformando suas práticas e ações. Disso resultam novas formas de exposição e de diálogo entre técnicos, especialistas, comunidades e público, configurando-se um processo de descolonização, no qual os objetos etnográficos, que foram depositados inertes 
nas reservas técnicas, ganhem um "estatuto polifônico e hermenêutico", 59 sujeitos a muitos olhares e interpretações.

A antropóloga Elsje Lagrou atribui eficácia e qualidade de agente aos artefatos dos Kaxinawá, do Acre, bem como aos seus adornos gráficos: "Os objetos são imbuídos de agência e são pensados como 'pessoas' de maneira parecida ao que foi observado no contexto melanésio". 60 Já os Wayana, que vivem na fronteira entre o Brasil, o Suriname e a Guiana Francesa, atribuem "ciclo vital" aos artefatos que "efetivamente nascem, possuem juventude quando desenvolvem atividades, adoecem e morrem". 61

Os antropólogos Fabíola Silva e Cesar Gordon registram que os objetos dos Xikrin, que vivem no estado do Pará, são vetores de subjetividade:

[...] os objetos, uma vez que são o resultado concreto de encadeamentos longos e complexos de relações sociais, jamais são puros objetos, coisas objetificadas, posto que carregam e encarnam subjetividades diversas, e estas podem sempre ser vivificadas, e se manifestar, desde que desejemos. Os objetos não deixam de estar vivos. ${ }^{62}$

Ao lado das novas teorias antropológicas, a nova museologia também provocou questionamentos quanto ao papel dos museus, da participação da coletividade e das questões de identidade. ${ }^{63}$ Como bem observa Marília Cury, não se trata de outra museologia, em contraposição à antiga, mas de "um modelo metodológico de interação entre o patrimônio cultural e a sociedade. Nesse modelo, o público é agente das ações de preservação e comunicação patrimonial e o processo é tomado como educacional, por ser transformador". ${ }^{64}$

A nova museologia, que promoveu a ampliação do conceito de patrimônio e abriu novos caminhos de investigação museológica, está relacionada ao aparecimento de novas categorias de museu (ecomuseu, museu comunitário, museu de vizinhança etc.) abertas à população e ao território. ${ }^{65}$ É somente com a participação da comunidade na qual o museu está inserido que ele pode ser "descolonizado culturalmente", 60 o que significa ter a comunidade como agente, promover a identidade territorial e democratizar o conhecimento. ${ }^{67}$

Cabe aos museus criar condições para conhecimento e entendimento do que seja identidade, de como, por que e para que ela se compartimenta e suas compartimentações se articulam e confrontam, quais os mecanismos e direções das mudanças e de que maneira todos esses fenômenos se expressam por intermédio das coisas materiais. A formulação de Hainard me parece pertinente para indicar a direção deste esforço: deve-se ir aos museus para interrogar e se interrogar, não para buscar respostas já concluídas. ${ }^{68}$
59. Lima Filho (2012, p. 111).

60. Lagrou (2003, p. 110).

61. Van Velthem (2003, p. 131).

62. Silva; Gordon (2011, p. 21).

63. Cerávolo (2004, p. 337).

64. Cury (2005, p. 63).

65. Santos (2011, p. 3).

66. Varine apud Bolaños (2002, p. 279).

67. Rivière apud Bolaños (2002, p. 284).

68. Meneses (1993, p. 214). 
69. Duarte (2013, p. 113).

70. O ICOM reafirma, por meio das resoluções aprovadas pela Conferência Geral de 2007 , seu próprio compromisso com as práticas éticas em museus, com a luta contra o tráfico ilícito, pelo apoio à restituição de bens culturais às comunidades de origem, preferencialmente através da mediação, e pela adoção de um conceito amplo de patrimônio universal, que inclua, em especial, o respeito pela diversidade cultural das comunidades ligadas a este patrimônio (International Council of Museums, 2004).

71. Bruno (2006, p. 17).

72. Marstine (2011, p. 17).

73. Kreps (2011, p. 79).

74. Botero (2013, p. 62)

75. Pearce (1992, p. 1).
Nessa perspectiva, Alice Duarte afirma que "o museu pode ser agente de mudança social, de regeneração e de empowerment das populações na medida em que se torne mais consciente da comunidade que o rodeia e se torne um efetivo espaço de congregação para essa comunidade". 69

O Museu de Arqueologia e Etnologia da Universidade de São Paulo (MAE/ USP), que possui um dos maiores acervos de etnologia e arqueologia do país, tem se alinhado ao Código de Ética para Museus ${ }^{70}$ e a favor de ações que colocam grupos indígenas em contato com a cultura material, incentivando discussões e ressignificações das coleções etnográficas. Seguindo as palavras da diretora do museu, Maria Cristina Bruno:

Nas últimas décadas, os museus têm desempenhado um papel relevante e específico no campo da democratização da cultura, rompendo as barreiras dos seus espaços tradicionais, procurando novos públicos e criando exposições que incorporam linguagens mistas. Estas instituições experimentam novos modelos de gestão, aproximam-se em programas de redes e sistemas, sem, entretanto, perder a noção de seu campo essencial de atuação. ${ }^{.1}$

Seguindo essa vertente, o MAE posiciona-se a favor do discurso ético como guardião do legado material dos povos indígenas, com o dever e a responsabilidade de conservar, salvaguardar e divulgar suas coleções. ${ }^{72} \bigcirc$ museu passa a atuar como co-curador das coleções com um crescente entendimento e respeito dos valores e significados que os objetos expostos podem ter para as comunidades. ${ }^{73}$

A presença das comunidades indígenas contemporâneas no Museu Nacional da Colômbia, por exemplo, possibilita a ressignificação dos objetos e a continuidade da história, contada pelas vozes indígenas. Para tanto, é preciso redesenhar as relações entre os museus e os povos indígenas, as quais devem ser ativas e se retroalimentar permanentemente, transformando o modo de ver. ${ }^{74}$ "Quando você está olhando um artefato, disse uma liderança indígena canadense, você está olhando para os pensamentos de uma pessoa". ${ }^{75}$

Os antropólogos Fabíola Silva e Cesar Gordon elaboraram o catálogo da coleção etnográfica Xikrin-Kayapó, do Museu de Arqueologia e Etnologia da Universidade de São Paulo, em 2003, contando com a participação dos índios Tamakware Xikrin e Kengore Xikrin e o apoio das comunidades Xikrin do Cateté e do Djudjêkó, que deram os nomes Xikrin dos objetos e descreveram suas funcionalidades, matérias-primas e técnicas de produção. Além disso, no processo de catalogação, excluíram alguns objetos que não pertenciam ao grupo.

A associação dos povos indígenas às práticas interpretativas das coleções desconstruiria a visão dos coletores e das técnicas museais vigentes e reconstruiria uma nova percepção das mesmas. A apreensão dos objetos etnográficos, enquanto artefatos dotados de uma 
função e uma significação, sofreria então uma mudança qualitativa, pois seria portadora de um poder evocativo e de mediação. Nessa ótica, os objetos etnográficos seriam apreendidos menos como testemunhos de culturas tradicionais e mais como suportes de um discurso identitário de povos longamente silenciados nessas instituições. ${ }^{76}$

A "descoberta dos museus pelos índios", 77 a partir da década de 1990, abre novas perspectivas tanto para os museus tradicionais - que passam a ter a participação de grupos indígenas no desenvolvimento de seus processos museológicos, questionando o discurso colonialista - quanto para os movimentos indígenas, que recriam, no espaço do museu, autorrepresentações, construções de identidades e "seus pontos de vista sobre a cultura", 78 que reverberam no cenário nacional e internacional. Nesse contexto, os museus indígenas se configuraram como espaço de lutas, interlocução cultural, afirmação de identidade, combate aos preconceitos e preservação do patrimônio material e imaterial.

Museu Maguta foi o primeiro museu indígena brasileiro, criado em 1991 pelos índios Ticuna, que vivem na região do Alto Solimões, em Benjamin Constant, na confluência dos rios Javari e Solimões, no Amazonas. Este pequeno museu reúne cinco salas de exposição e uma pequena biblioteca.

Uma parte de sua coleção foi formada com o trabalho de artistas indígenas, especializados em diferentes artes: confecção de máscaras rituais, esculturas de madeira e de coco-de-palmeira, pintura de painéis decorativos de entrecasca, fabricação de colares, cestos, redes e bolsas. Outra parte, com a recuperação de certos artefatos hoje já em processo de extinção ou em desuso, reconstituídos a partir de fotografias antigas pertencentes a museus etnográficos, entrevistas com anciãos e registros feitos desde 1929 pelo etnólogo Curt Nimuendajú.79

Os Ticuna notaram a importância do museu como meio de fortalecimento da identidade e da memória e de dissolução de ideias preconceituosas a respeito das populações indígenas. Não é à toa que o Museu Maguta surge no seio da luta pela demarcação de terras, como instrumento de mobilização e defesa do território Ticuna, ameaçado por latifundiários, políticos e madeireiros que, atribuindo aos índios uma identidade "cabocla", expropriavam suas terras. ${ }^{80}$ "A ideia da criação de um museu surgia como estratégia de organização da memória e revigoração da identidade étnica", 81 além de mobilizar lutas pelos direitos indígenas. Segundo depoimento do líder Ticuna Constantino Ramos Lopes Cupeatücü:

A intenção da criação do museu era que os índios não perdessem tudo o que tinham, já que mesmo suas armas como a zarabatana não sabiam mais fabricar, além de serem obrigados pelos patrões a plantar mandioca e fabricar farinha para ser vendida em Benjamin
76. Van Velthem (2012 p. 64).

77. Freire (1992).

78. Vidal (2008).

79. Freire (1992).

80. "Em março de 1988, pistoleiros atacaram um grupo de índios no igarapé do $\mathrm{Ca}$ pacete, matando catorze deles, entre homens, mulheres e crianças, ferindo 23 e deixando dez desaparecidos, num massacre que teve ampla repercussão nacional e internacional" (Abreu, 2008, p. 134).

81. Abreu (2008, p. 134). 
82. Abreu (2008, p. 137).

83. Abreu (2008, p. 135).

84. Abreu (2008, p. 137).

85. Abreu (2008, p. 138).

86. "O etnônimo Kanindé remete ao chefe indígena Canindé, principal dos Janduins, que liderou a resistência de seu povo no século XVII, obrigando o então rei de Portugal a assinar com ele um tratado de paz, firmado em 1692, mas descumprido por parte dos portugueses (Gomes; Vieira Neto, 2009, p. 93).

87. Gomes; Vieira Neto (2009, p. 92).

88. Gomes; Vieira Neto (2009, p. 39).
Constant, Tabatinga e Letícia na Colômbia. A ideia de criar o museu foi para preservar a arte e a língua ticuna, assim como o mito e a história. ${ }^{82}$

acervo possui mais de 420 peças e foi formado pelas lideranças indígenas, que mobilizaram aproximadamente 95 aldeias da região, com uma população de 28 mil índios. O processo contou com a assessoria da antropóloga Jussara Gomes Gruber.

O principal trabalho consistiu, de um lado, em recuperar antigas tradições e técnicas artesanais em desaparecimento e, de outro lado, estimular os artistas indígenas, especializados em diferentes artes (confecção de máscaras rituais, esculturas de madeira e de cocos-de-palmeira, pinturas de painéis decorativos de entrecasca, fabricação de colares, cestos, redes e bolsas). ${ }^{83}$

Projetado e dirigido pelos líderes do Conselho Geral da Tribo Ticuna, o Museu Maguta deu visibilidade nacional e internacional aos Ticuna. Com ações museológicas voltadas para o presente, o primeiro museu indígena inscreve-se "numa ação de resistência ou até mesmo de re-existência". ${ }^{84}$ Em 1996, recebeu o prêmio do International Council of Museums (Comitê Internacional de Museus Icom) e, em 2008, o Prêmio Chico Mendes do Ministério do Meio Ambiente.

Trata-se, portanto, de uma experiência pioneira no campo dos museus etnográficos, que serviu de modelo para a proliferação de outros museus dos povos indígenas no Brasil, com ativa participação das comunidades nas quais estão inseridos. "O falar sobre o 'outro' é substituído por uma narrativa que mescla a construção da alteridade com a autorrepresentação e construção de si" ${ }^{85}$

O Museu dos Kanindé, ${ }^{86}$ em Aratuba, no Ceará, é uma experiência museal que "ocorre concomitante ao processo de mobilização étnica". ${ }^{87}$ Os índios do Ceará, que haviam sido considerados extintos no século XIX, realizam, depois da Constituição de 1988, "o caminho de volta" às suas identidades indígenas.

A emergência étnica ocorre junto às articulações políticas destas comunidades sob a categoria identitária indígena e em etnônimos específicos [...]. Inicia-se o processo de diferenciação, de redescoberta, de busca de sinais diacríticos em relação à sociedade envolvente. ${ }^{88}$

Instalado na Aldeia Fernandes, em um compartimento de uma casa simples, - Museu do Kanindé foi fundado por José Maria Pereira dos Santos, mais conhecido como Cacique Sotero, responsável pela coleta dos objetos reveladores da vida indígena em vários tempos e da ligação dos índios com a mata. "Percebemos que 
a caça e os conhecimentos referentes à fauna e à flora locais constituem importantes sinais diacríticos desta comunidade indígena". 89 Segundo o Cacique Sotero:

Aqui é a experiência de nossa comunidade. Tem gato-maracajá, camaleão, peba, mão-de-onça, tejo, pé-de-veado, nosso artesanato em madeira de imburana. Aqui é um fuso da minha tia, couro de jirita, corvja, inxuí de abelha de dá mel. A gente derruba na mata e come o mel. Bolsa de palha de carnaúba, o casco de um tatu. Aqui as nossas vestes, que nós usa nos ritual. Vamos fazer uma representação, que o povo gosta sempre de chamar a gente, a sociedade [...] também na escola com as crianças. ${ }^{90}$

Museu foi aberto ao público em 1996, em meio à luta pela afirmação da indianidade dos Kanindé, como um instrumento mobilizador da identidade étnica. Os museus do Ceará, portanto, cumpriram um papel importante no processo de etnogênese das populações indígenas, que se articula aos movimentos políticos pelo direito às terras originais.

Museu Kuahí, ${ }^{91}$ dos povos indígenas do Oiapoque, localizado no Amapá, extremo norte do Brasil, fronteira com a Guiana Francesa, reúne acervos dos grupos Karipuna, Palikur, Galibi-Marworno e Galibi-Kali'na, povos indígenas do Baixo Oiapoque que se originaram de várias migrações e fusões, mas que, atualmente, compartilham um mesmo território, conectados pelos rios Oiapoque, Curiti, Uaçá e Urukuá, estabelecendo laços de solidariedade e de parentesco.

Depois de viagem de algumas lideranças indígenas à Alemanha, França e Portugal, em companhia da então esposa do governador do estado do Amapá e secretária estadual, Janete Capiberibe, os povos do Oiapoque decidiram organizar um museu, com o apoio do governador do Amapá, João Alberto Capiberibe, em 1998. Inaugurado em 19 de Abril de 2007, o Museu Kuhaí, que conta com a assessoria da antropóloga Lux Vidal, é uma instituição indígena de referência e memória dos povos do norte amazônico, viabilizando ainda a comercialização da produção artesanal e a geração de renda. ${ }^{92}$ A parceria Secult/AP e Ministério da Cultura permitiu a formação dos educadores do museu e forneceu os equipamentos das instalações: salas de exibição, reserva-técnica, auditório, sala de processamento de documentos, biblioteca, sala de leitura, sala de pesquisa e sala do educativo. Na entrada do museu, há uma loja onde são vendidos artefatos. ${ }^{93}$

A coleção é formada por mais de 300 peças - todas elas encomendadas e produzidas nas aldeias - que representam os artefatos mais expressivos de uso cotidiano e ritual, além de peças fabricadas para o comércio. 94 "O Museu thes aparece, assim, como mais uma conquista dos movimentos indígenas". 95 Em entrevista, Lux Vidal relembra as concepções indígenas em relação aos objetos na
89. Gomes; Vieira Neto (2009, p. 96)

90. Gomes; Vieira Neto (2009, p. 92).

91. Explica Lux Vidal que Kuhají é o nome de um pequeno peixe na região e o nome dado a um padrão gráfico muito utilizado na decoração de objetos (Vidal, 2008, p. 109).

92. Vidal (2008, p. 110).

93. Vidal (2013, p. 403).

94. Vidal (2008, p. 114).

95. Vidal (2008, p. 114). 
96. Macedo; Grupioni (2009, p. 802).

97. Vidal (2013, p. 408).

98. Abreu; Lima Filho (2012, p. 48).

99. No plano internacional, destacam-se os museus tribais do Noroeste da América do Norte, a rede de museus comunitários mexicanos, os museus dos aborígenes australianos e o Museu Nacional SênecaIroquês e a Associação de Museus Indígenas Americanos (Gomes, 2014, p. 2).

100. Abreu (2007).

101. Clifford (1997, p. 192) apud Ashley (2005, p. 37). primeira exposição do museu, intitulada "A presença do invisível: vida cotidiana e ritual entre os povos indígenas do Oiapoque", montada no Museu do Índio em 2007:

Na grande exposição inaugural do Kuahí, em 2007, os índios quiseram expor todo o acervo de que dispunham. Montaram a exposição, com pouco critério museológico, mas o conjunto expressava uma dimensão cosmológica, a relação dos objetos com o invisível. Percebíamos que aqueles objetos eram mesmo coisas vivas, cópias dos invisíveis. $\bigcirc$ pote de caxiri estava no alto de um suporte e parecia um karuanã, um encantado, uma coisa que dominava o resto, as esculturas dos seres sobrenaturais. ${ }^{96}$

Em 2010, quando a equipe do museu reorganizou a exposição, mudou a organização inicial, exibindo, de um lado, objetos cotidianos e, de outro, rituais. Para cada categoria, apenas um objeto era exibido: "The Indians said that the way that it was before they could not explain to the school groups and other visitors the order of the exhibition".97

O Museu Kuhaí apresenta a perspectiva indígena da produção cultural dos povos do Oiapoque. Dentro dos museus, os representantes das comunidades indígenas assumem o papel de curadores, antropólogos, pesquisadores.

Neste caso, trata-se não apenas de estudar os museus, os objetos e as coleções, mas de ouvir o "outro" que foi objeto das práticas colecionistas e das representações museológicas. É importante assinalar que, neste processo, o "nativo" também passa a incorporar a técnica da museologia, e alguns chegam mesmo a estudar museologia". 98

Os três museus indígenas pioneiros no Brasil99 aqui descritos serviram de estímulo para a emergência de outros museus, capazes de conferir novos sentidos às exposições, aos objetos, às apropriações das coleções, dos acervos e dos patrimônios e ao espaço museal. As ações museológicas indígenas, ao contrário dos museus tradicionais, seguem a lógica do pensamento ameríndio e operam em direção à afirmação das identidades étnicas. Os museus indígenas possibilitam, portanto, a construção de uma "antropologia nativa" 100 que, ao difundir as vozes e perspectivas silenciadas no passado, propiciam a abertura de novos caminhos tanto para a antropologia quanto para os museus.

Para concluir, os museus no século XXI têm um importante papel na renovação cultural dos povos indígenas no mundo contemporâneo. Esse desafio requer que os museus, lugares de contato, de conflito e de interação da comunidade, ${ }^{101}$ repensem suas práticas e ações. "Isso exige que a equipe do museu olhe para além das paredes de suas próprias instituições e da comunidade local e reconheça os valores e necessidades das comunidades de origem, 
considerando a contribuição que podem fazer para a sociedade como um todo, e não apenas para seus visitantes e para a comunidade acadêmica". ${ }^{102}$

\section{CONSIDERAÇÕES FINAIS}

Os museus não são mais depósitos de objetos etnográficos que testemunham culturas extintas, mas têm a obrigação ética de receber os grupos indígenas que queiram ver a coleção de artefatos produzida por seus antepassados. A intersecção entre os agentes que trabalham nos museus e os grupos indígenas produz novos significados aos objetos, sejam eles arqueológicos ou etnográficos. Fabíola Silva e Cesar Gordon entendem

uma coleção etnográfica como um documento que pode ter muitas possibilidades de leitura. Ela é formada a partir de uma determinada visão do coletor, em um contexto complexo de interação com os produtores, em momento histórico particular. Ao mesmo tempo, ela é constituída por objetos que possuem uma história e uma realidade própria, cujos significados são múltiplos e que não se reduzem, evidentemente, à lógica institucional dos museus e ao sistema de classificação museográfica. ${ }^{103}$

diálogo, portanto, torna-se peça-chave nos museus etnográficos, cujo saber constituído na lógica do colonialismo deve ser revisto e submetido aos olhos e à análise dos grupos indígenas. "O museu, nascido como espaço público de representação de um saber institucionalizado, como templo da modernidade, somente pode sobreviver em meio aos debates da contemporaneidade se é capaz de se transformar em ágora, em um espaço aberto de diálogo e confrontação". ${ }^{104}$

A cultura material das populações nativas das terras baixas da América do Sul, que hoje se encontra sob a salvaguarda de museus brasileiros, não é apenas "patrimônio da nação", mas também patrimônio dos grupos indígenas que a produziram, "uma vez que são testemunhos de formas de vida particulares que revelam ou expressam evidências do nosso passado, do passado dos povos indígenas com os quais se erigiu a nação". ${ }^{105}$

Nesse sentido, os museus etnográficos enfrentam atualmente o desafio e a obrigação ética tanto de divulgar os seus acervos de cultura material como de abrir espaços de diálogo e de reflexão com as populações indígenas. Para tanto, devem se converter em espaços que considerem também os espíritos como outra dimensão possível de compreensão e leitura dos objetos manufaturados. "Por qué estos espíritus están en prisión?", questiona um xamã no sótão do Museu Nacional da Colombia. ${ }^{106}$
102. Simpson (2009, p. 121, tradução minha).

103. Silva; Gordon (2011, p. 19).

104. Iniesta (2001, p. 28, tradução minha).

105. Grupioni (2008, p. 29).

106. Londoño (2012, p. 735). 
Para Lévi-Strauss, a cestaria, por exemplo, goza de muito prestígio entre os povos indígenas porque

[...] os espíritos das cestas, dizem, vivem na decoração trançada: é seu povo. Por esta dita decoração, deve incluir uma "porta": efeito intencionado, normalmente apenas visível, que rompe a continuidade do motivo e que permite ao espírito da cesta, quando esta morre, escapar e subir ao céu. ${ }^{107}$

Somente os espíritos livres dos artefatos e as vozes indígenas são capazes de libertar os museus de seus grilhões etnocêntricos e de suas narrativas de exclusão. 


\section{REFERÊNCIAS}

ABREU, Regina. Tal antropologia qual museu? In: Revista do Museu de Arqueologia e Etnologia, São Paulo, v. S7, p. 121-143, 2008.

ABREU, Regina; LIMA FILHO, Manuel Ferreira. A trajetória do GT de Patrimônios e Museus da Associação Brasileira de Antropologia. In: TAMASO, Izabela; LIMA FILHO, Manuel Ferreira (org). Antropologia e patrimônio cultural: trajetórias e conceitos. Brasília, DF: Associação Brasileira de Antropologia, 2012. p. 25-57.

ALENCAR, José de. Iracema. São Paulo: Ática, 2002.

ANDERMANN, Jens. Espetáculos da diferença: a Exposição Antropológica Brasileira de 1882. Topoi, Rio de Janeiro, v. 5, n. 9, p. 128-170, jul./dez. 2004.

ANDERSON, Benedict. Comunidades imaginadas: reflexões sobre a origem e a difusão do nacionalismo. São Paulo: Companhia das Letras, 2008.

ASHLEY, Susan. First nations on view: Canadian Museum and hybrid representations of culture. In: INTERSECTIONS, 2005, Toronto. Selected papers... Toronto: eTopia, 2005. Disponível em: <https://bit.ly/2GwugA2>. Acesso em: 27 mar. 2018.

BANCEL, Nicolas; BLANCHARD, Pascal: LEMAIRE, Sandrine. Ces zoos humains de la République coloniale. Le Monde Diplomatique, Paris, p. 16-17, out. 2000. Disponível em: <https://bit.ly/2GbWgcL>. Acesso em: 19 out. 2017.

BERGER, John. Ways of seeing. London: Penguin, 1972.

BOLAÑOS, Maria (org.). La memoria del mundo: cien años de museologia (1900-2000). Gijón: Trea, 2002.

BOTERO, Clara Isabel. La cultura material indígena en el Museo Nacional: perspectivas y consideraciones. Baukara, Bogotá, n. 3, p. 57-63, maio 2013.

BRUNO, Maria Cristina Oliveira. Museologia e Museus: os inevitáveis caminhos entrelaçados. Cadernos de Sociomuseologia, n. 25, p. 5-20, 2006. 
CANDIDO, Antonio. Formação da literatura brasileira, vol. 1. Belo Horizonte: Itatiaia; São Paulo: Edusp, 1975.

CARNEIRO DA CUNHA, Manuela. História dos índios no Brasil. São Paulo: Companhia das Letras, 1992.

CASTRO, Grasielle. O Brasil vive uma guerra e não sabe, diz Vincent Carelli, diretor de Martírio. HuffPost Brasil, São Paulo, 23 set. 2016. Disponível em: <https://bit.ly/2GBbebw>. Acesso em: 27 mar. 2018.

CERÁVOLO, Suely Morais. Em nome do céu, o que é Museologia? Perspectivas de museologia através de publicações. Revista do Museu de Arqueologia e Etnologia, São Paulo, n. 14, p. 311343, 2004.

CLIFFORD, James. The predicament of culture: twentieth-century etnography, literature, and art. Cambridge: Harvard University Press, 1988.

COLONIALISM. In: STANFORD Encyclopedia of Philosophy. Palo Alto: Stanford University, 2017. Disponível em: <https://stanford.io/2pZlboV>. Acesso em: 2 abr. 2018.

CURY, Marília Xavier. Museologia: marcos referenciais. Cadernos do CEOM, Chapecó, v. 18, n. 21, p. $45-73,2005$.

DOLHNIKOFF, Miriam. O projeto nacional de José Bonifácio. Novos Estudos Cebrap, São Paulo, n. 46, p. 121-141, nov. 1996.

DUARTE, Alice. Nova museologia: os pontapés de saída de uma abordagem ainda inovadora. Revista Eletrônica do Programa de Pós-Graduação em Museologia e Patrimônio, Rio de Janeiro, v. 6, n. 1, p. 99-117, 2013.

FRANÇOZO, Mariana de Campos. De Olinda a Olanda: Johan Maurits van Nassau e a circulação de objetos e saberes no Atlântico holandês (séc. XVII). 2009. 296 f. Tese (Doutorado em Ciências Sociais) - Instituto de Filosofia e Ciências Humanas da Universidade de Campinas, Campinas, 2009.

De Olinda a Holanda: o gabinete de curiosidades de Nassau. Campinas: Editora Unicamp, 2014.

FREIRE, José R. Bessa. A descoberta dos museus pelos índios. Terra das Águas, Brasília, DF, v 1, n. 1, 1999. Disponível em: <https://bit.ly/2GdKCJu>. Acesso em: 14 maio 2018. 
GOMES, Alexandre Oliveira. Por uma antropologia dos museus indígenas: práticas de colecionamento, categorias nativas e regimes de memória. In: REUNIÃO BRASILEIRA DE ANTROPOLOGIA, 29, 2004, Natal. Anais... Brasília, DF: Associação Brasileira de Antropologia, 2004.

GOMES, Alexandre Oliveira; VIEIRA NETO, João Paulo. Museus e memória indígena no Ceará: uma proposta em construção. Fortaleza: Secult, 2009.

GORBACH, Frida. Los indios del Museo Nacional: la polémica teratológica de la pátria. Ciencias, México, DF, n. 60, p. 57-63, 2001.

GRUPIONI, Luis Donisete Benzi. Museu, identidades e patrimônio cultural. Revista do Museu de Arqueologia e Etnologia, São Paulo, v. S7, p. 21-32, 2008.

INIESTA, Montserrat. Historias y museos. Cuaderno Central, Barcelona, n. 55, p. 25-29, abr./jun. 2001.

INTERNATIONAL COUNCIL OF MUSEUMS. Código de ética do Icom para museus. São Paulo: Comitê Brasileiro do Icom, 2004.

KODAMA, Kaori. Em busca da gênese do Brasil nas Províncias do Norte: Gonçalves Dias e os trabalhos etnográficos da Comissão Científica de Exploração. In: KURY, Lorelai (org.). Comissão Científica do Império 1859-1861. Rio de Janeiro: Andrea Jakobson Estúdio, 2009a. p. 114-153.

Os índios no Império do Brasil: a etnografia do IHGB entre as décadas de 1840 e 1860. Rio de Janeiro: Editora Fiocruz; São Paulo: Edusp, 2009b.

KREPS, Christina. Changing the rules of the road: post-colonialism and the new ethics of museum anthropology. In: MARSTINE, Janet (org.). The Routledge Companion to museum ethics: redefining ethics for the twenty-first century museum. London: Routledge, 2011.

KURY, Lorelai (org.). Comissão Científica do Império 1859-1861, Rio de Janeiro: Andrea Jakobson Estúdio, 2009.

LAGROU, Elsje Maria. Antropologia e arte: uma relação de amor e ódio. Ilha Revista de Antropologia, Florianópolis, v. 5, n. 2, p. 93-113, dez. 2003.

LARAIA, Roque de Barros. Da ciência biológica à social: a trajetória da antropologia no século XX. Habitus, Goiânia, v.3, n.2, p. 321-345, jul./dez. 2005. 
LIMA FILHO, Manuel Ferreira. Entre campos: cultura material, relações sociais e patrimônio cultura. In: LIMA FILHO, Manuel Ferreira; TAMASO, Izabela Maria (org.). Antropologia e patrimônio cultural: trajetórias e conceitos. Brasília: Associação Brasileira de Antropologia, 2012.

LONDOÑO, Wilhelm. Espíritus en prisión: una etnografia del Museo Nacional de Colombia. Chungara, Arica, v. 44, n. 4, p. 733-745, 2012.

MACEDO, Valéria; GRUPIONI, Luís Donisetti. Exposições e invisíveis na antropologia de Lux Vidal. Revista de Antropologia, São Paulo, v. 32, n. 2, p. 789-814, 2009.

MALINOWSKI, Bronislaw. Argonautas do Pacífico Ocidental: um relato do empreendimento e da aventura dos nativos nos arquipélagos da Nova Guiné, Melanésia. São Paulo: Abril Cultural, 1976.

MARQUES, Luiz. Catálogo do Museu de Arte de São Paulo Assis Chateaubriand: arte do Brasil e demais coleções. São Paulo: Prêmio, 1998.

MARSTINE, Janet. The contingent nature of new museum ethics. In: MARSTINE, Janet (org.). The Routledge Companion to museum ethics: redefining ethics for the twenty-first century museum. London: Routledge, 2011.

MATTOS, Isabel Missagia de. Civilização e revolta: os Botocudos e a catequese na Província de Minas. Santa Catarina: Edusc, 2003.

MAUSS, Marcel. Sociologia e antropologia. São Paulo: Cosac Naify, 2003.

MAZÉ, Camille. Des musées de la nation aux musées de l'Europe. Vacillement, maintien ou renforcement d'um modèle? In: ROLLAND, Anne-Solène; MURAUSKAYA, Hanna (org.). Les musées de la nation: créations, transpositions, renouveaux, Europe XIXe-XXIe siècles. Paris: L'Harmattan, 2008.

MENESES, Ulpiano T. Bezerra de. A problemática da identidade cultural nos museus: de objetivo (de ação) a objeto (de conhecimento). Anais do Museu Paulista, v. 1, n. 1, p. 207-309, 1993.

MONTEIRO, John H. Tupis, Tapuias e historiadores: estudos de história indígena e do indigenismo. 2001. 235 f. Tese (Livre-Docência) - Universidade de Campinas, Campinas, 2001.

MORENO, Luis Gerardo Morales. Origenes de la museologia mexicana: fuentes para el estúdio histórico del Museo Nacional, 1780-1940. México, DF: Universidad Iberoamericana, 1994.

Vieja y nueva museologia en México. In: GANT, María Luisa Bellido (org.). Aprendiendo de Latinoamérica: el museo como protagonista. Gijón: Trea, 2007. p. 343-374. 
. Museu, memória e historicidade na museologia mexicana. In: VASCONCELLOS, Camilo de Mello; FUNARI, Pedro Paulo; CARVALHO, Aline (org.). Museus e Identidades na América Latina. São Paulo: Annablume, 2015. p. 189-209.

MOURA, Carlos Eugênio Marcondes de. Estou aqui. Sempre estive. Sempre estarei: Indígenas do Brasil. Suas imagens (1505-1955). São Paulo: Edusp, 2012.

MURATORIO, Blanca. Discursos y silencios sobre el indio en la conciencia nacional. In: . Imágenes e imagineros: representaciones de los indígenas ecuatorianos, siglos XIX y

XX. Quito: Facultad Latinoamericana de Ciencias Sociales, 1994. p. 361-375.

NASCIMENTO, Fátima Regina. A formação da coleção de indústria humana no Museu Nacional, século XIX. 2009. 271. Tese (Doutorado em Antropologia Social) -Universidade Federal do Rio de Janeiro, Rio de Janeiro, 2009.

PEARCE, Susan M. Museums, objects, and collections. Washington, DC: Smithsonian, 1992.

Interpreting objects and collections. Londres: Taylor and Francis, 2002.

POMIAN, Krzysztof. Colecção. In: Enciclopédia Einaudi. Porto: Imprensa Nacional; Casa da Moeda, 1984.

QUIJANO, Aníbal. Colonialidade do poder, eurocentrismo e América Latina. In: LANDER, Edgardo (org.). A colonialidade do saber: eurocentrismo e ciências sociais: perspectivas latinoamericanas. Buenos Aires: Consejo Latinoamericano de Ciencias Sociales, 2005. p. 227-278.

RIBEIRO, Berta Gleizer; VAN VELTHEM, Lucia Hussak. Coleções etnográficas: documentos materiais para a história indígena e a etnologia. In: CARNEIRO DA CUNHA, Manuela (org). História dos índios no Brasil. São Paulo: Companhia das Letras, 1998.

SANTOS, Maria Célia Teixeira Moura. Os museus e a busca por novos horizontes. BiblioTextos, [S.1.], 10 dez. 2011. Disponível em: <https://bit.ly/2Gi8NHB>. Acesso em: 27 mar. 2018.

SCHWARCZ, Lilia Moritz. O espetáculo das raças: cientistas, instituições e questão racial no Brasil, 1870-1930. São Paulo: Companhia das Letras, 2007.

SCRICH, Eduardo. O último Tamoio, de Rodolfo Amoedo. In: ENCONTRO DE HISTÓRIA DA ARTE, 5., 2009, Campinas. Anais... Campinas: Unicamp, 2009. p. 385-397.

SILVA, Fabíola Andréa; GORDON, Cesar (orgs.). Xikrin: uma coleção etnográfica. São Paulo: Edusp, 2011. 
SIMPSON, Moira. Museums and restorative justice: heritage, repatriation and cultural education. Museum International, Hoboken, v. 61, n. 1-2, p. 121-129, 2009.

STOCKING JR., George W. (org). Objects and others: essays on Museum and Material Culture. Wisconsin: The University of Wisconsin Press, 1985.

TACCA, Fernando de. O índio na fotografia brasileira: incursões sobre a imagem e o meio. História, Ciência, Saúde, Rio de Janeiro, v. 18, n. 1, p. 191-223, jan./mar. 2011.

VAN VELTHEM, Lúcia Hussak. O belo é a fera: a estética da produção e da predação entre os Wayana. Lisboa: Museu Nacional de Etnologia, 2003.

O objeto etnográfico é irredutível? Pistas sobre novos sentidos e análises. Boletim do Museu Paraense Emílio Goeldi, Belém, v. 7, n.1, p. 51-66, jan./abr. 2012.

VARNHAGEN, Francisco Adolfo. História Geral do Brasil. São Paulo: Melhoramentos, 1948. v.1.

VIDAL, Lux Boelitz. O museu dos povos indígenas do Oiapoque-Kuahí: gestão do patrimônio cultural pelos povos indígenas do Oiapoque, Amapá. Revista do Museu de Arqueologia e Etnologia, São Paulo, v. S7, p. 109-115, 2008.

Kuahí: the indians of the lower Oiapoque and their museum. Vibrant, Brasília, DF, v. 10 , n. 1, p. 387-423, jan./jun. 2013.

VON MARTIUS, Carl Friedrich Philipp. Como se deve escrever a História do Brasil. Jornal do Instituto Histórico e Geográfico Brasileiro, n. 24, p. 381-403 jan. 1845.

ZEITOUN, Charlie. À l'époque des zoos humains. CNRS Le Journal, Paris, 25 ago. 2015. Disponível em: <https://bit.ly/1PwoQ2e>. Acesso em: 14 maio 2018.

Artigo apresentado em 07/11/2017. Aprovado em 21/03/2018

All the contents of this journal, except where otherwise noted, is licensed under a Creative Commons Attribution License

\section{(cc) BY}

